\title{
Quantifying heterogeneous transport of a tracer and a degradable contaminant in the field, with snowmelt and irrigation
}

\author{
D. Schotanus, M. J. van der Ploeg, and S. E. A. T. M. van der Zee \\ Correspondence to: D. Schotanus (dieuwke.schotanus@wur.nl) \\ Received: 4 April 2012 - Published in Hydrol. Earth Syst. Sci. Discuss.: 16 April 2012 \\ Revised: 11 July 2012 - Accepted: 25 July 2012 - Published: 21 August 2012
}

Soil Physics, Ecohydrology and Groundwater Management, P.O. Box 47, 6700 AA Wageningen, The Netherlands

\begin{abstract}
To examine the persistence of preferential flow paths in a field soil, and to compare the leaching of a degradable contaminant with the leaching of a tracer, two field experiments were performed using a multi-compartment sampler (MCS). The first experiment was carried out during the snowmelt period in early spring, characterized by high infiltration fluxes from snowmelt. The second experiment was carried out in early summer with irrigation to mimic homogeneous rainfall. During the second experiment, the soil was warmer and degradation of the degradable contaminant was observed. For both experiments, the highest tracer concentrations were found in the same area of the sampler, but the leached tracer masses of the individual locations were not highly correlated. Thus, the preferential flow paths were stable between the two experiments. With a lower infiltration rate, in the second experiment, more isolated peaks in the drainage and the leached masses were found than in the first experiment. Therefore, it is concluded that the soil heterogeneity is mainly caused by local differences in the soil hydraulic properties, and not by macropores. With higher infiltration rates, the high and low leaching cells were more clustered. The leached masses of the degradable contaminant were lower than the leached masses of the tracer, but the masses were highly correlated. The first-order degradation rate and the dispersivity were fitted with CXTFIT; the first-order degradation rate was $0.02 \mathrm{~d}^{-1}$, and the dispersivity varied between 1.9 and $7.1 \mathrm{~cm}$. The persistence of the flow paths during the experiments suggests soil heterogeneity as the driver for heterogeneous flow and solute transport in this soil. At the MCS scale, heterogeneous snowmelt did not seem to have much influence on the flow and solute paths.
\end{abstract}

\section{Introduction}

Preferential flow can lead to rapid transport of nutrients and chemicals through the unsaturated zone, which can result in groundwater contamination. Preferential flow processes are generally studied at either the core, profile or landscape scale (Allaire et al., 2009). Soil heterogeneity hinders the prediction of the movement of mass in field situations, because it often results in faster movement of water and solutes than would be expected from the soil matrix properties. When effective parameters are used for soil and climatic properties, contaminant leaching may be underestimated by a hydrologic model (Allaire et al., 2009). To account for preferential flow in the models, additional parameters are needed to quantify the importance of preferential flow in a field soil (Feyen et al., 1998; Šimunek et al., 2003). It is important to identify the main process that causes preferential flow, when solute transport is modelled. As the soil is a complex system, field experiments can give better insight into which processes are important for the occurrence of preferential flow. Based on this knowledge, a better prediction can be made of the potential risk of groundwater contamination for a particular soil and contaminant.

Preferential flow can be caused by macropore flow (Jarvis, 2007) or spatial variability of the hydraulic properties (Roth, 1995). When the flow rate is high compared to the saturated hydraulic conductivity of the soil, most of the soil is close to saturation. Under these conditions, coarse textured regions are better conductors than fine textured regions (Roth, 1995). Therefore, coarser textured regions are likely to develop flow channels with a vertical orientation under a high infiltration rate. With a water flux that is much lower than the saturated hydraulic conductivity, flow channels will also develop, 
but then in the fine textured regions instead of the coarse textured.

Preferential flow paths may change in time due to bioactivity, or due to complete saturation or drying of the soil (Öhrström et al., 2004). Williams et al. (2003), Lennartz et al. (2008) and Buchter et al. (1995) found that preferential flow paths are stable. Most studies investigated the leaching of tracers, while the effect of preferential flow on the degradation of degradable contaminants is highly relevant for the potential contamination risk for natural systems (Flury, 1996). The rapid transport in macropores, compared to the matrix, leads to a higher leaching of a degradable contaminant than when only matrix flow occurs (Pot et al., 2005).

When degradation of contaminants is studied, the experimental conditions should resemble the natural field conditions as closely as possible, because the degradation rate depends on temperature and soil moisture content, amongst others (Stotzky, 1997). Furthermore, in a structured soil, degradation may be lower than in a mixed sample, because micro-organisms or the substrate cannot enter all aggregates (Chenu and Stotzky, 2002). Also when soil heterogeneity is quantified, the soil structure should be intact. Most studies have been done in the laboratory, under different conditions than in the field (Quisenberry et al., 1994; Buchter et al., 1995; Pot et al., 2005), and hence may under- or overestimate the soil heterogeneity. Estimations of the effect of soil heterogeneity on contaminant leaching may be more realistic in the field, using wick samplers (Holder et al., 1991; Boll et al., 1997) or suction plates (Kasteel et al., 2007). A disadvantage of wick samplers is that the pressure that is applied to the soil is constant. Using suction plates, the ambient soil pressure may be applied (Weihermüller et al., 2007). For both wick samplers and suction plates, the patial resolution may be too coarse (around $100 \mathrm{~cm}^{2}$ ) to capture all small scale flow processes (Poletika and Jury, 1994; Buchter et al., 1995). To overcome these disadvantages, a multi-compartment sampler (MCS) as introduced by Bloem et al. $(2009,2010)$ was used in our study, in which the pressure is adjusted according to the pressure in the surrounding soil. Additionally, the spatial resolution of the MCS is high, and therefore, fluxes through individual $3.15 \times 3.15 \mathrm{~cm}^{2}$ can be measured.

The spatial pattern in leaching of a degrading contaminant might be different than a tracer as a result of differences in travel times. Examples of degradable contaminants for which a travel time distribution in the unsaturated zone may help to estimate the leaching to the groundwater are easily degradable contaminants like pesticides (Flury, 1996). Another easily degradable contaminant is propylene glycol (PG), which is used in de-icing chemicals at airports (Jaesche et al., 2006; French et al., 2001). Propylene glycol is degradable by micro-organisms, and non-adsorbing to soil particles (French et al., 2001). At Oslo airport in Norway de-icing chemicals are used to remove snow and ice from airplanes before departure during winter time. Although this is done on a platform to collect the de-icing chemicals, a fraction of these de-icing chemicals can contaminate the snow surrounding the runway. During snowmelt, the infiltration rates are high, and the de-icing chemicals can be transported rapidly through the coarse textured soil on which the airport is located (French and Van der Zee, 1999). Groundwater contamination with the de-icing chemical should be avoided, as the airport is located on a large unconfined aquifer (French et al., 2001).

Snowmelt may add extra heterogeneity to the water flow, as a snow cover acts as a porous medium, in which meltwater can flow in preferential paths (Waldner et al., 2004; Marsh, 1991). Furthermore, the rate of snowmelt can differ locally which introduces more heterogeneous flow at the plot scale, with horizontal differences in infiltration (French and Van der Zee, 1999).

It has not been investigated often which particular process is responsible for the preferential leaching of a tracer in a field soil. Furthermore, experiments on preferential leaching usually focus on non-degradable tracers, while the preferential leaching of a degradable contaminant might be different. Two field experiments were performed, using the MCS, to quantify the spatial variability in solute leaching, to quantify possible seasonal effects, and to compare the leaching of a tracer with degradable PG. The first experiment was done during the snowmelt period in early spring. This experiment was characterized by high infiltration fluxes from the meltwater and a frozen soil. Furthermore, the heterogeneous flow in the snow cover might result in infiltration at the soil surface that is not uniformly distributed. The second experiment was done in late spring/early summer with irrigation to mimic homogeneous rainfall with known infiltration amounts. In the second experiment, the soil was warmer and degradation of the degradable contaminant was observed.

With the two experiments we answer the following research questions: (1) How persistent is preferential flow in the field for two cases with different boundary conditions? (2) How different is the spatial variability in leaching for a tracer and a degradable solute? (3) What determines the heterogeneous flow in this soil: soil heterogeneity, the infiltration rate, or snowmelt heterogeneity?

\section{Materials and methods}

\subsection{Experiment}

To measure spatial and temporal variability in solute leaching and drainage a multi-compartment sampler (MCS) (Bloem et al., 2010) was installed at the field station Moreppen, near Oslo Airport, Norway. Details about the field station can be found in French et al. (1994). The field station is located in a flat area with coarse glaciofluvial sediments (sand and gravel) (French and Van der Zee, 1999). The soil is an Entic Haplorthods (French et al., 2001). The texture distribution is $15 \%$ fine sand, $75 \%$ medium and coarse sand, and $10 \%$ 
gravel (French et al., 1994). The saturated hydraulic conductivity is $6.65 \times 10^{-4} \mathrm{~m} \mathrm{~s}^{-1}$ (French et al., 2001). The soil surface was covered with short grass. The MCS has a size of $31.5 \times 31.5 \mathrm{~cm}^{2}$, and consists of 100 separate drainage collectors. The surface of the MCS consists of porous metal plates, to which pressure can be applied. Details about the MCS can be found in Bloem et al. (2010).

From a trench a horizontal tunnel was dug, leaving the soil above this tunnel undisturbed. The tunnel was secured with a wooden frame, to prevent the surrounding soil from collapsing. At $68 \mathrm{~cm}$ distance from the trench wall, the MCS was installed at $51 \mathrm{~cm}$ below soil surface (Fig. 1). A $2 \mathrm{~mm}$ thick layer of wetted soil from the tunnel was applied to the surface of the MCS, to ensure a good contact between the MCS and the soil above it. The wooden frame was removed, and the tunnel was backfilled, to avoid boundary effects. Four tensiometers were installed near the trench wall, at $51 \mathrm{~cm}$ depth. The average pressure head measured by the four tensiometers was applied to the MCS, plus $15 \mathrm{~cm}$ extra pressure head to compensate for a pressure head drop in the porous metal plates (Bloem et al., 2009). The pressure in the MCS was variable in time.

Two experiments were done: one during snowmelt (26 March-23 May 2010) and one with irrigation (23 May4 July 2010). For the snowmelt experiment $1092 \mathrm{~g} \mathrm{~m}^{-2}$ propylene glycol (PG) and $10 \mathrm{~g} \mathrm{~m}^{-2}$ bromide was diluted in $21 \mathrm{~m}^{-2}$, and sprayed uniformly on top of an undisturbed snow cover (26 March 2010). De-icing fluid (Kilfrost, 2012) containing PG was diluted to reach this applied mass. The application area was large enough to ensure that boundary effects can be neglected. In the snowmelt experiment the infiltration originated from snowmelt or rainfall. Snowmelt was measured daily by measuring the depth and equivalent water depth of the snow cover at three locations at the field station. At these locations, no de-icing chemical was applied. The snow in the application area melted faster than at these locations, due to the de-icing chemical. On 12 April, the snow was patchy above the MCS, and at 13 April all snow above the MCS was melted. The difference of the equivalent water depth of the snow cover per day, plus the rainfall, was the infiltration per day (Fig. 2). The infiltration originating from the snowmelt occurred 1 or 2 days earlier in the area where PG was applied, than in the area were the snowmelt was measured. We will ignore this difference, as it is not important for the current data analysis. No ice layer was found below the snow cover, at the soil surface. This means that the possible heterogeneous infiltration of meltwater was not attributable to ice.

For the irrigation experiment $1103 \mathrm{~g} \mathrm{~m}^{-2} \mathrm{PG}$ and $10 \mathrm{~g} \mathrm{~m}^{-2}$ bromide was diluted in $51 \mathrm{~m}^{-2}$, and sprayed uniformly on the soil surface at 23 May 2010. Also in the irrigation experiment, the application area was large enough to ensure that boundary effects can be neglected. The irrigation scheme and the daily mean air temperature are given in Fig. 3. Initially, the irrigation rate was based on the measurements from

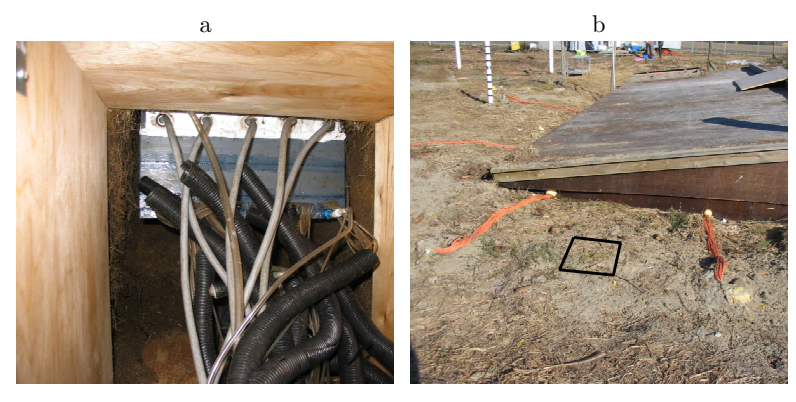

Fig. 1. Experimental setup. Installation of the multi-compartment sampler (MCS), shown from the trench (a). The location of the MCS shown from above (b). The marked square indicates the location of the MCS, $51 \mathrm{~cm}$ below soil surface. The roof of the trench is visible in the background. The width of the MCS is $31.5 \mathrm{~cm}$.

the snowmelt experiment, such that the irrigation experiment could be finished in the limited time that was available for it. However, during the irrigation experiment, the transport of bromide was found to be too slow. Therefore, the irrigation rate was increased from 2 June onward. In between the irrigations, the soil surface was covered with plastic, to minimize evapotranspiration and to avoid the infiltration of rainwater. Using a nozzle, the soil surface was irrigated with tap water, except on 12 June. This was a rainy day and $7.8 \mathrm{~mm}$ of rainwater infiltrated, while the plastic was removed. On 13 June, $7.5 \mathrm{~mm}$ water was irrigated. The irrigation rate was approximately $6.6 \mathrm{~mm} \mathrm{~h}^{-1}$. Neither surface runoff, nor ponding was observed. Between 31 May and 2 June, evaporation was measured in a pan under the plastic. The measured evaporation was $1 \mathrm{mmd}^{-1}$. These were warm days, the average evapotranspiration rate during the entire irrigation experiment probably was lower.

Drainage was stored in the MCS, samples were taken with a frequency that depended on the amount of drainage. For the snowmelt experiment, samples were taken daily from 1 April until 15 April. Then, samples were taken at 17 and 21 April, and 9 and 23 May. During the irrigation experiment, samples were taken every second day, on the same day as, and prior to, the irrigations. After collecting, the samples were weighted to determine the volume of drainage. If a sample was smaller than $4 \mathrm{ml}$, it was stored cool. In the next sampling round, the sample was added to this stored small sample. In samples larger than $4 \mathrm{ml}$, the bromide concentration was measured with an Orion 9635BNWP Bromide Ion Selective Electrode. Besides, in the irrigation experiment, the PG concentration was measured with a GC analyser. We assumed that degradation of PG during the snowmelt experiment was low, due to the low temperature and high PG concentration in the applied solution (Jaesche et al., 2006). Therefore, the PG concentration was not measured in the snowmelt samples. At the end of the experiment, all samples that still were smaller than $4 \mathrm{ml}$ after the final sampling round were mixed, and $\mathrm{Br}$ and $\mathrm{PG}$ were measured in this mixed sample. 

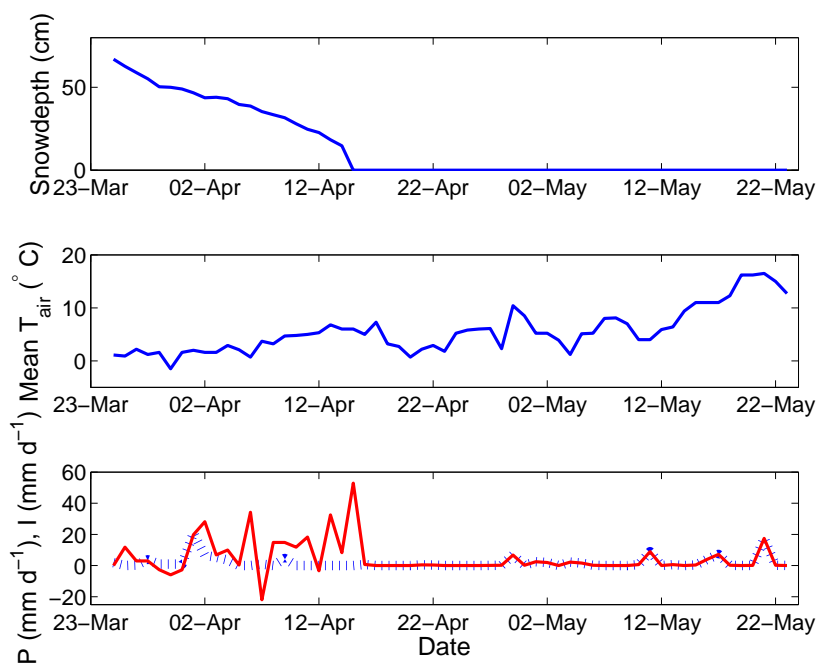

Fig. 2. Weather series for the snowmelt experiment (in 2010), mean $T_{\text {air }}$ is the daily mean temperature $\left({ }^{\circ} \mathrm{C}\right), P$ is the daily precipitation ( $\mathrm{mm} \mathrm{d}^{-1}$, dotted blue line), $I$ is the infiltration $\left(\mathrm{mm} \mathrm{d}^{-1}\right.$, red line). The daily infiltration is calculated from the sum of the change in the equivalent water depth of the snow cover in a day, and the precipitation.

\subsection{Data analysis}

The experiment lead to a data set with volumes of drainage, and leaching concentrations for each sampling round and each cell. With drainage, we refer to water volumes that were collected, while we use leaching to refer to solute masses. To quantify how the drainage, or the leaching in a particular cell is related to the drainage, or leaching in a neighbouring cell, we calculate the spatial autocorrelation using Moran's I (Strock et al., 2001):

$I=\frac{n}{S_{0}} \frac{\sum_{i} \sum_{j} W_{i j}\left(X_{i}-\bar{X}\right)\left(X_{j}-\bar{X}\right)}{\sum_{i}\left(X_{i}-\bar{X}\right)^{2}}, \quad S_{0}=\sum_{i} \sum_{j \neq i} W_{i j}$

where $n$ is the number of cells, $W_{i j}$ is a measure of the neighbouring of the cells $i$ and $j$, and $X_{i}$ is the measured total drainage, or solute leaching in cell $i$. Cells are neighbours when they share one side. This means that $W_{i j}$ is 2 for the cells in the corners, 3 for the cells at the borders, and 4 for the other cells. In $I$ both the values of drainage and leaching, and the spatial information, with the weighing $W_{i j}$, are included. $I$ varies between -1 and 1 , where 1 means that the values of neighbouring cells are perfectly positively autocorrelated. When there is no autocorrelation, the expected value of $I$ is $-1 /(n-1)$, which is -0.010 with 100 cells.

The velocity, dispersivity, and first order degradation constant were estimated by fitting de convection-dispersion equation to the breakthrough curves with the parameter fitting program CXTFIT (Toride et al., 1995). The dispersivity that was estimated for bromide, was also used for PG. The velocity and first-order degradation constant for PG were fitted.
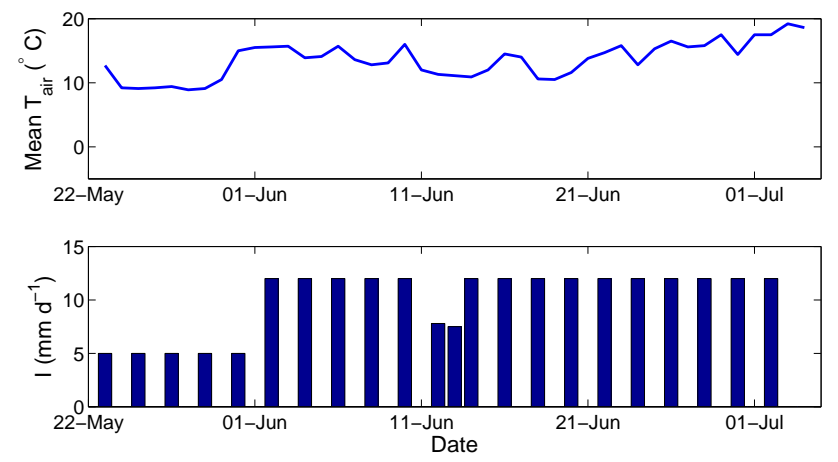

Fig. 3. Weather series for the irrigation experiment (in 2010), mean $T_{\text {air }}$ is the daily mean temperature $\left({ }^{\circ} \mathrm{C}\right), I$ is the infiltration from irrigation $\left(\mathrm{mm} \mathrm{d}^{-1}\right)$.

\section{Results and discussion}

\subsection{Stability of the spatial patterns of drainage and concentration in time}

We will start with describing the spatial patterns of drainage and solute concentrations to determine the stability of these patterns during and between the snowmelt and the irrigation experiment.

Figure 4 shows the spatial distribution of the volume of drainage, and of the bromide concentration during the snowmelt experiment at five selected cumulative drainage depths (the amount of total drainage since solute application). The cumulative drainage depth is used as a time axis instead of the day (Wierenga, 1977), to facilitate a comparison with the irrigation experiment, which had a different infiltration rate. The bromide concentration is scaled with the applied mass of bromide per $\mathrm{m}^{2}$, to facilitate a comparison with propylene glycol (PG) during the irrigation experiment later on. The initial bromide concentration was not used for scaling, because the applied bromide was diluted with meltwater from the snow.

At $13 \mathrm{~mm}$ after solute application, drainage started in the left middle part of the sampler. At $66 \mathrm{~mm}$, most cells drained water, but the highest water fluxes were still found in the left middle part. Throughout the snowmelt experiment, the highest drainage volumes were found in this area. The bromide concentrations were low in the first drainage at $13 \mathrm{~mm}$. The highest bromide concentrations could be found in the lower left part of the sampler at $44 \mathrm{~mm}$ of drainage. At $66 \mathrm{~mm}$, the maximum bromide concentrations were lower than at $44 \mathrm{~mm}$. At $66 \mathrm{~mm}$, bromide leached through a larger part of the sampler and the concentrations were more equally spread in space than at $44 \mathrm{~mm}$. At $103 \mathrm{~mm}$ of drainage, the concentrations decreased further, and the highest concentrations were now found on the right side. At $121 \mathrm{~mm}$ of drainage, the drainage did not contain bromide anymore. 


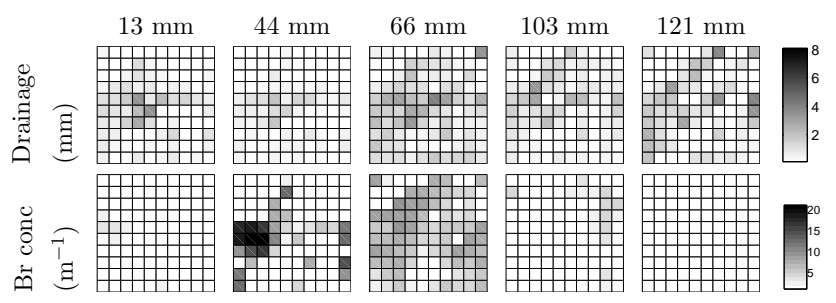

Fig. 4. Spatial distributions of the drainage, and the bromide concentration during the snowmelt experiment over the multicompartment sampler consisting of $10 \times 10$ cells of $3.15 \times 3.15 \mathrm{~cm}^{2}$ each. The bromide concentration is scaled with the applied mass per $\mathrm{m}^{2}$. The titles refer to the cumulative drainage since solute application.

The drainage patterns showed more isolated peaks than the bromide concentration. The cells with the highest drainage did not necessarily leach the highest concentration of bromide. The spatial pattern of the bromide concentration had a larger variation in time than the pattern of drainage. From Fig. 4 it is clear that both water flow and solute transport in this soil are heterogeneous.

Figure 5 shows the spatial distributions of the volume of drainage, of the bromide concentration, and of the PG concentration during the irrigation experiment at five selected cumulative drainage depths. During the irrigation experiment, water drained over the whole MCS, with a few isolated peaks that were stable throughout the irrigation experiment. Bromide leaching started at $70 \mathrm{~mm}$, the highest bromide concentrations were found in the lower left area of the sampler. At $101 \mathrm{~mm}$, the bromide concentrations peaked in the lower left, the middle right area, and in the upper left cell. Around those peaks, cells also started leaching bromide, but generally with lower concentrations. At $124 \mathrm{~mm}$, most cells leached bromide and the differences between the concentrations of the cells were small. At $124 \mathrm{~mm}$, the concentrations decreased relatively to the concentrations at $101 \mathrm{~mm}$. In the irrigation experiment, bromide leaching started after a larger amount of drainage than during the snowmelt experiment. Thus, at the start of the irrigation experiment, more water was stored between the soil surface and the MCS than at the start of the snowmelt experiment.

Like the bromide concentration, the PG concentration first increased in the lower left part (at 41 and $70 \mathrm{~mm}$ ). At $101 \mathrm{~mm}$, the concentrations were lower than at $70 \mathrm{~mm}$, the highest concentrations were found on the right side of the sampler. At $124 \mathrm{~mm}$, the drainage did not contain PG anymore. The leaching of PG started earlier than the leaching of bromide. This was also observed by French et al. (2001), and may be caused by density driven flow. The density of pure de-icing fluid is 1.043 times the density of pure water (Kilfrost, 2012). After dilution the density of the applied solution was approximately 1.005 times the density of water. The PG concentrations decreased both earlier and faster than the bromide concentration. The faster decrease in

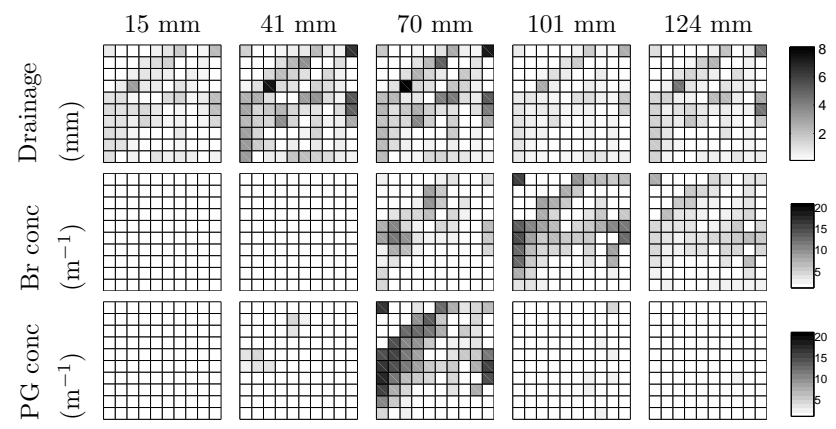

Fig. 5. Spatial distributions of the drainage, the bromide concentration, and the PG concentration during the irrigation experiment over the multi-compartment sampler consisting of $10 \times 10$ cells of $3.15 \times 3.15 \mathrm{~cm}^{2}$ each. The concentrations of bromide and PG are scaled with the applied mass per $\mathrm{m}^{2}$. The titles refer to the cumulative drainage since solute application.

the concentration can be attributed to degradation of PG by micro-organisms. French et al. (2001) found that the first order degradation constant for PG in a field soil was between 0.015 and $0.04 \mathrm{~d}^{-1}$. Fitted from the breakthrough curves of bromide and PG for the entire MCS, we found a first order degradation constant of $0.02 \mathrm{~d}^{-1}$ for PG during the irrigation experiment.

Figure 6 shows the mean pressure head at $51 \mathrm{~cm}$ depth. The pressure head was generally higher during the snowmelt period than during the irrigation experiment. Peaks in the pressure head during the snowmelt resulted from infiltrating meltwater during warmer days. The maximum pressure heads from the snowmelt and the irrigation experiment were similar, but during the snowmelt experiment, the soil drained less than during the irrigation experiment. The average pressure head was $-27 \mathrm{~cm}$ during the snowmelt experiment (26 March-23 May), $-16 \mathrm{~cm}$ during the snowmelt period (26 March-12 April), and $-25 \mathrm{~cm}$ during the irrigation experiment (23 May-4 July). During the snowmelt period, when high infiltration rates occur, the soil is wetter, and therefore a larger part of the coarse textured soil is even higher conductive than under drier conditions as in the irrigation experiment. In the irrigation experiment, the drainage showed more isolated peaks than for the snowmelt experiment. Williams et al. (2003) showed that the degree of preferential flow resulting from macropore flow would increase with increasing flow rate. In the snowmelt experiment with higher infiltration rates, however, the number of isolated peaks in the drainage decreased (comparing the drainage in Figs. 4 and 5). The heterogeneous flow in the soil, therefore, is probably caused by small changes in the soil hydraulic properties, and not by macropores.

Figure 7 shows the areas of the MCS in which the highest concentrations, as plotted in Figs. 4 and 5, were measured. For both the snowmelt and the irrigation experiment, the areas with the highest concentrations are similar. In the snowmelt experiment, the differences in concentrations 


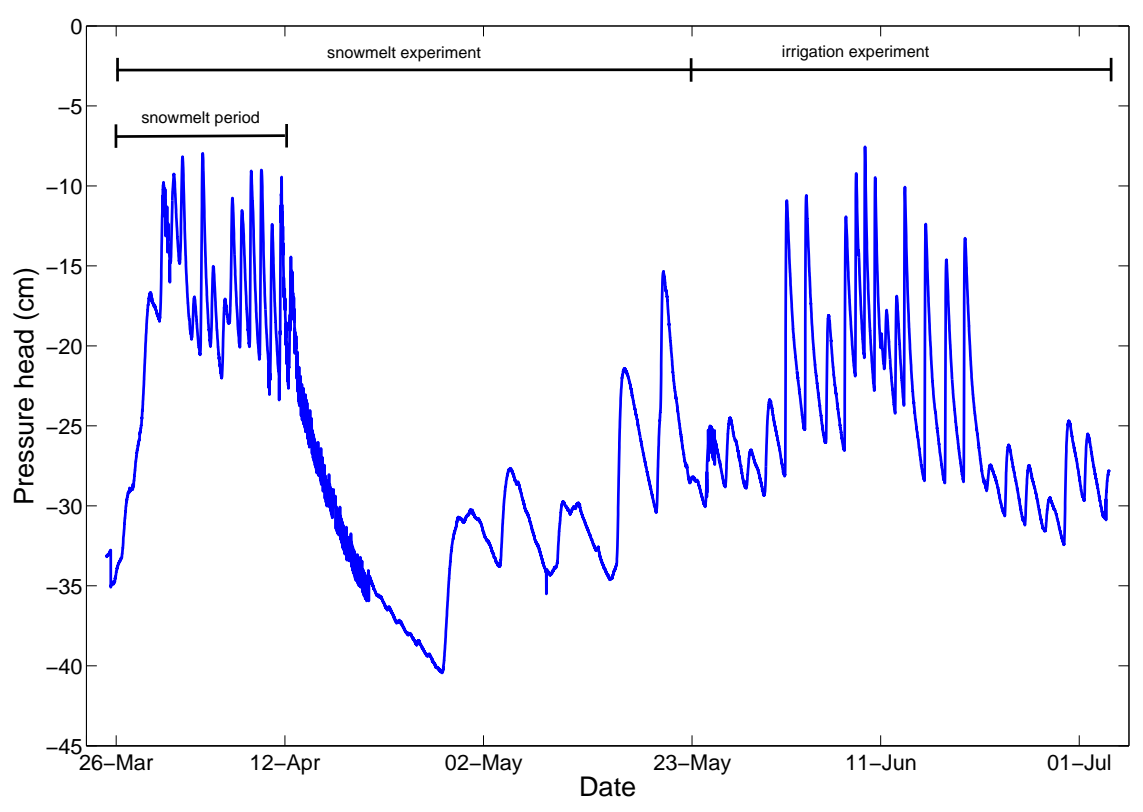

Fig. 6. Average pressure head $(\mathrm{cm})$ at $51 \mathrm{~cm}$ depth during the snowmelt and the irrigation experiment (in 2010).

between all cells seem to be larger than during the irrigation experiment. The high concentrations in a small area of the sampler can be caused by snowmelt. With a high infiltration rate and a wet soil, a small part of the soil can transport solutes rapidly, while little dilution occurs due to a low exchange with the surrounding soil, as lateral mixing is time dependent. This leads to a larger spatial variability in concentrations than for the lower infiltration rates during the irrigation experiment. The differences in the concentrations were not caused by heterogeneous infiltration of the meltwater from the snow. If this was the case, also the drainage should be heterogeneous, with the same spatial patterns as the concentration, which was not observed (Fig. 4). Based on this, it is concluded that the infiltration of the meltwater was homogeneous, compared to the soil heterogeneity. Results from a preliminary experiment, which was performed during the spring of 2009, confirm this conclusion. The areas with the highest leaching were similar for 2009 and 2010, which means that the effect the heterogeneous infiltration of meltwater is small compared to the effect of soil heterogeneity.

Based on the snowmelt and irrigation experiment we conclude that generally, the spatial patterns of the concentration are similar with high or low infiltration rates, but the differences between the concentrations are larger with a high infiltration rate.

During the irrigation experiment, the highest PG concentrations, and the highest bromide concentrations can be found in the same areas, but at different times. Thus, the spatial patterns in the concentrations of a tracer and a degradable solute are similar.

\subsection{Effect of the travel time distribution on BTCs}

Figures 4 and 5 reveal that the soil consisted of fast and slow responding areas. Buchter et al. (1995) made a division of the soil in fast and slow cells, based on the height of the peak concentration of the BTC, and the moment that this peak concentration was reached. For each cell, we determined the number of days from solute application until the peak concentration was reached. The resulting histograms are shown in Fig. 8. It must be mentioned that the irrigation experiment was ended before the BTCs were complete for all cells. Cells in which the concentration was still increasing at that time, mostly have their highest concentration at day 40 or 41 , which then is called the peak concentration in Fig. 8. There were 11 cells that did not leach during the irrigation experiment, these are not included in Fig. 8. For the snowmelt experiment, the histogram has a bell-shaped distribution, and shows that most cells reached the peak concentration at 15 days after solute application. For the irrigation experiment, the histogram is not bell-shaped.

Based on the histograms, the cells are divided in three groups: fast, average, and slow cells. Fast cells are the cells that leach before the mode (before day 15 in the snowmelt experiment, and before day 30 in the irrigation experiment). Average cells have their peak concentration when most cells have (at day 15 and 16 in the snowmelt experiment, and at day 30 in the irrigation experiment). Slow cells have their peak concentration later than the average cells (after day 16 in the snowmelt experiment, and after day 30 in the irrigation experiment). Cells can belong to different groups for the snowmelt and the irrigation experiment. The average concentrations of bromide and PG were calculated for the groups of 


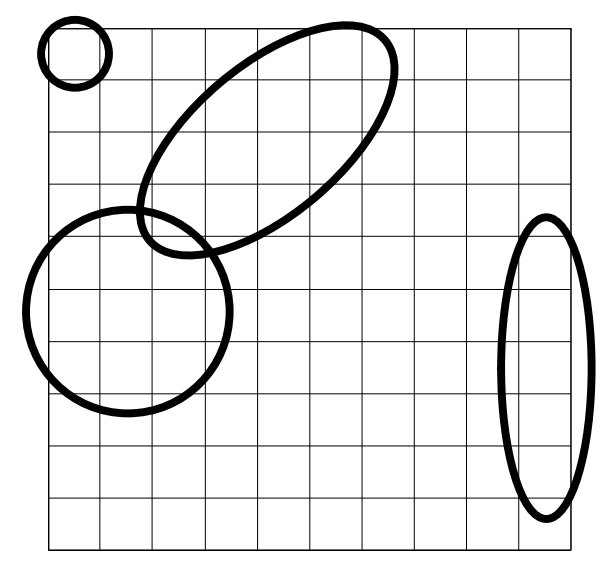

Fig. 7. The areas from the multi-compartment sampler where the highest leaching of bromide and PG occurred (based on Figs. 4 and 5).

cells. The BTCs of the fast, average, and slow cells for bromide during the snowmelt and the irrigation experiment are given in Fig. 9.

During the snowmelt experiment, the bromide concentration increased rapidly in the fast cells, as a result of the high infiltration rate caused by snowmelt. At $66 \mathrm{~mm}$ of drainage, only patchy snow was left above the MCS. The bromide concentration decreased rapidly in the fast cells when the snow had melted ( $79 \mathrm{~mm}$ drainage). In the snowmelt experiment, the height of the concentration peak was higher than in the irrigation experiment, probably as a result of the higher infiltration rate. The bromide concentration also increased earlier in the snowmelt experiment than in the irrigation experiment. The value of the peak concentration decreased from fast to slow cells in both the snowmelt and the irrigation experiment. This is expected, as the spreading generally increases with time, which will lead to a lower peak concentration for a non-degradable solute.

For the BTCs in Fig. 9, the solute transport parameters from the convection-dispersion equation were fitted using CXTFIT (Toride et al., 1995). For the fitting, the cumulative drainage of the entire sampler was used as a time axis, to obtain the required steady state conditions (Wierenga, 1977). This gives the velocity $v$ a unit of $\mathrm{cm} \mathrm{mm}^{-1}$, and the dispersion coefficient $D$ a unit of $\mathrm{cm}^{2} \mathrm{~mm}^{-1}$. Using the average drainage per day during either the snowmelt or the irrigation experiment, the parameters were back-transformed to units of $\mathrm{cmd}^{-1}$, and $\mathrm{cm}^{2} \mathrm{~d}^{-1}$ (Table 1). From the fitted parameters the dispersivity $\alpha$ was calculated $(\alpha=D / v)$. Both $v$ and $D$ decrease from fast to slow cells for the snowmelt and the irrigation experiment. As expected, for the fast and average cells, the velocities are higher during the snowmelt than the irrigation experiment. This is caused by the higher infiltration rate, resulting from the snowmelt. Based on the results of Vanderborght and Vereecken (2007) for a database with a large number of laboratory and field experiments,

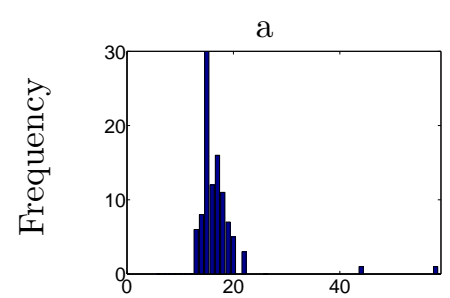

Day since application

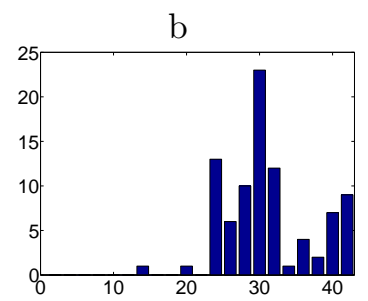

Day since application
Fig. 8. Histograms of the day number on which the peak bromide concentration occurred, for the snowmelt experiment (a), and the irrigation experiment (b). Application was on 26 March 2010 (a), and 23 May 2010 (b).

Table 1. Solute transport parameters with pore water velocity $v$ $\left(\mathrm{cm} \mathrm{d}^{-1}\right)$, and dispersivity $\alpha(\mathrm{cm})$ for fast, average, and slow cells, as well as for the entire sampler, for bromide.

\begin{tabular}{llcc}
\hline Experiment & Group & $v\left(\mathrm{~cm} \mathrm{~d}^{-1}\right)$ & $\alpha(\mathrm{cm})$ \\
\hline \multirow{2}{*}{ Snowmelt } & Fast & 1.8 & 6.6 \\
& Average & 1.5 & 7.1 \\
& Slow & 1.3 & 2.4 \\
& Total & 1.7 & 5.6 \\
\hline \multirow{2}{*}{ Irrigation } & Fast & 1.5 & 4.1 \\
& Average & 1.4 & 3.8 \\
& Slow & 1.3 & 2.0 \\
& Total & 1.6 & 1.9 \\
\hline
\end{tabular}

both the flow rate and the flow conditions affect the dispersivity values that are found. As the flow rate increases, they found that dispersivities tend to increase, for relatively small transport distances as in the present study. We find that for the snowmelt experiment, the dispersivity of the fast cells is larger than the dispersivity of the average and slow cells. For the irrigation experiment, the dispersivity increases from slow to average to fast cells. In that respect, our results comply with those of the database. Our dispersivity values are generally of equal value, or perhaps a bit smaller, than those of the database. However, our flow rates on average are smaller than in the shorter travel distance situations (core, column) of the database. Moreover, not only the mean flow rate may affect the dispersivity, but also the flow regime. For conditions similar to our experiments, with natural climate and intermittent irrigation upper boundary, Vanderborght and Vereecken (2007) found that smaller dispersivity ranges result in their database. The dispersivities were lower during the irrigation experiment than during the snowmelt experiment, which may have periodically larger flow rates, particularly near the soil surface (Figs. 2 and 3). This is also in agreement with the database results. Also compared with the review of Beven et al. (1993) our observations agree well.

We hypothesize that in fast cells, the values of the peak concentration (relative to the applied concentrations) of PG 


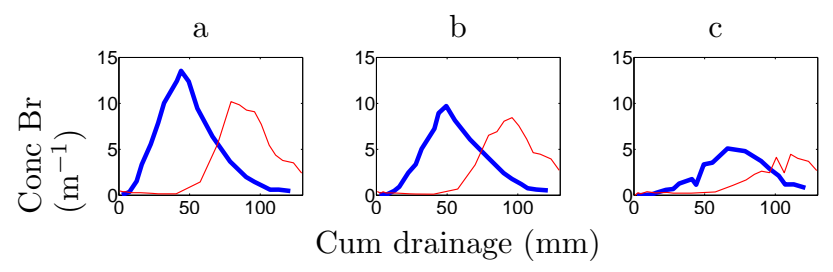

Fig. 9. Breakthrough curves of bromide for the snowmelt experiment (thick blue line) and the irrigation experiment (thin red line), for fast cells (a), average cells (b), and slow cells (c).

and bromide would be similar, because PG degradation can only occur during a short period. In slow cells, the travel time is longer, and therefore, more PG would be degraded than in the fast cells. As a result, in slow cells, the PG concentration would be lower than the bromide concentration, and this difference would increase with increasing travel time.

Figure 10 shows the BTCs for PG and bromide in the irrigation experiment, for the fast, average, and slow cells. For the fast cells, the PG concentration increased earlier than the bromide concentration. This was also observed by French et al. (2001), and can be caused by density-driven flow. The values of the peak concentration and the recession thereafter were similar for bromide and PG. The average cells show comparable features, but with lower concentrations than for the fast cells. Also, the PG concentration decreased earlier than the bromide concentration in the average cells, which possibly is attributable to degradation.

Initially, the PG concentrations in the fast and average cells might have been too high for the micro-organisms, and therefore degradation might have been inhibited. PG degradation can be inhibited if the PG concentration is high, and the inhibition limit depends on the type of micro-organisms, and temperature, amongst others (Bausmith and Neufeld, 1999; Jaesche et al., 2006). The first order degradation rate of PG increases with a decreasing PG concentration (Bausmith and Neufeld, 1999). Once the concentration was below the inhibition level, as was probably the case in the average cells, the concentration decreased rapidly due to degradation. In the slow cells, PG was degraded before bromide reached the peak concentration. Thus, in the slow cells the PG concentration appears to decrease faster than in the fast cells, the decrease in the bromide concentration appears to be similar in the fast, average, and slow cells. This means that the degree of degradation of PG would increase from fast to slow cells. The degradation constant was only fitted for the entire sampler $\left(k=0.02 \mathrm{~d}^{-1}\right)$, and not for the fast, average, and slow cells separately, because the BTCs of bromide are not complete. The incomplete BTCs hinder the estimation of the degradation constants, mainly in the slow cells.

We conclude that the travel time distribution influences the concentrations of degradable solutes, and the differences between the concentrations of degradable and nondegradable solutes increase from fast to slow transporting

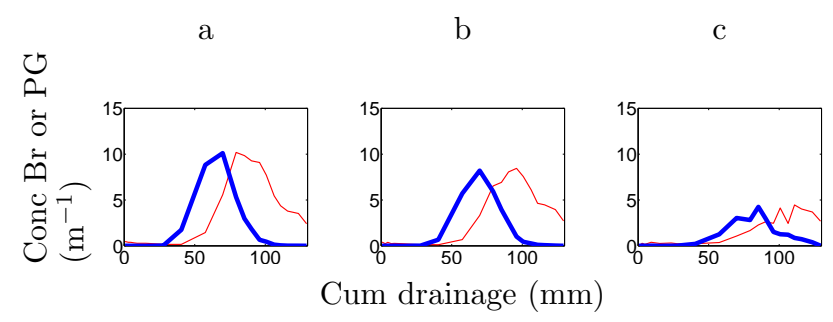

Fig. 10. Breakthrough curves of bromide (thin red line) and PG (thick blue line) for the irrigation experiment, for fast cells (a), average cells (b), and slow cells (c).

areas. Therefore, in parts of the soil that transport water and solutes rapidly, the leaching of degradable contaminants will be higher than in slow transporting areas.

\subsection{Spatial patterns of total drainage and leaching}

The conclusion drawn from Fig. 10 was that the degradation of PG appears to increase from fast to slow cells. To further examine this conclusion, we will discuss the spatial pattern of the total leached masses of bromide for both the snowmelt and the irrigation experiment, and PG for the irrigation experiment.

Figure 11 shows the total leached mass of bromide for the snowmelt experiment, for the irrigation experiment, and the total leached mass of PG during the irrigation experiment, together with the relative differences between the leached PG and bromide (Fig. 11d). The leached masses of PG and bromide should be compared with some caution, because the bromide BTCs were not complete for all cells before the experiment was stopped. Therefore, the total bromide leaching was underestimated, especially for slow cells.

From Fig. 11a and b follow that the highest bromide leaching occurred in the same area for the snowmelt and the irrigation experiment. In the snowmelt experiment, most leaching occurred in the middle left part of the sampler, while in the irrigation experiment, most leaching occurred in the areas that are marked in Fig. 7. In the low leaching areas, the leaching was higher during the snowmelt experiment than during the irrigation experiment. Apparently, with high infiltration rates, as in the snowmelt experiment, the leaching was more homogeneous. More homogeneous leaching was caused by more homogeneity in drainage, because the spatial variability in the concentration was larger in the snowmelt experiment than in the irrigation experiment (Fig. 4). The more homogeneous drainage can be caused by the higher infiltration rate, which results in a wetter soil. In a wetter soil, a larger part of the matrix drains water than in a drier soil, because the hydraulic conductivity is higher. Furthermore, Fig. 11a and $\mathrm{b}$ show that in the irrigation experiment, with low infiltration rates, there were more isolated peaks in the leached masses than in the snowmelt experiment. 


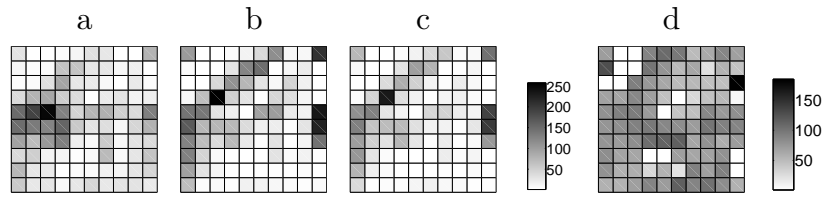

Fig. 11. Spatial distributions of the total bromide leaching during snowmelt, total bromide leaching during irrigation, and total PG leaching during irrigation over the multi-compartment sampler consisting of $10 \times 10$ cells of $3.15 \times 3.15 \mathrm{~cm}^{2}$ each. Bromide leaching during the snowmelt experiment (a), bromide leaching during the irrigation experiment (b), PG leaching during the irrigation experiment (c), leaching is given in \% from what would have leached in each cell with perfect uniform flow. PG leaching divided by bromide leaching during the irrigation experiment (d), both scaled with the applied solute mass per $\mathrm{m}^{2}$, given in $\%$.

The spatial patterns in the bromide and PG leaching during the irrigation experiment were similar (Fig. 11b, c). Figure 11d shows that the PG leaching was generally lower than the bromide leaching (i.e. less than $100 \%$ ). In the upper right area of the MCS, the leaching of PG was smallest compared to bromide, but also since little bromide was leached that was not well visible in Fig. 11b and c. Thus, the spatial distributions of the leached masses are similar, because the leaching of the non-degradable solute in this area was low as well. The highest PG concentrations, and the highest bromide concentrations can be found in the same areas, but at different times (Fig. 5), and the cumulative leached masses were similar. This means that the spatial pattern of the drainage was stable in time during the irrigation experiment.

During the snowmelt experiment, the bromide recovery was $43 \%$. During the irrigation experiment, the bromide recovery was $42 \%$, and the PG recovery was $32 \%$. The low bromide recovery suggests flow bypassing the sampler. However, in a closed lysimeter experiment from the same area, the bromide recovery was $42 \%$ (Lißner et al., 2011). Thus, the extent of flow bypassing the sampler is probably much lower than would be expected based on the bromide recovery. On average for all cells and for the entire irrigation experiment, the leaching of PG is $75 \%$ from the bromide leaching, which suggests that $25 \%$ of the PG was degraded during this experiment. As mentioned before, the BTCs of bromide were not complete before the irrigation experiment was stopped, and thus the bromide leaching was underestimated. This implies that the PG degradation was also underestimated.

\subsection{Quantifying preferential flow}

Figures 4, 5, and 11 give a visual representation of the results. In the following section we will quantify differences in the spatial distribution of the leaching of bromide and PG, and the drainage.

For this purpose, the cells are sorted with decreasing drained volume or leached mass, and then cumulated as

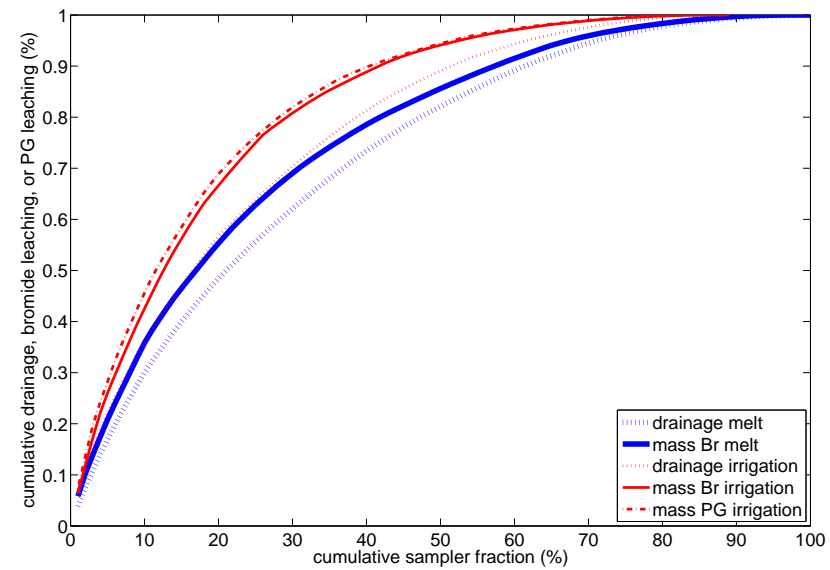

Fig. 12. Normalised cumulative drainage and leaching of bromide during the snowmelt and irrigation experiments, and PG during the irrigation experiment. The drainage and the leaching per cell were scaled with the total drainage or the total leached mass for the sampler during either the snowmelt experiment or the irrigation experiment. The cells are sorted with decreasing amount of drainage, bromide, or PG leaching.

proposed by Quisenberry et al. (1994), Strock et al. (2001), and De Rooij and Stagnitti (2002). The sorting of the cells removed all spatial information. The cumulative drainage and leaching are plotted as a function of the cumulative sampler area in Fig. 12. The cumulative sampler area is defined as the surface area of the number of cells that corresponds to the number of the sorted drained volume or leached mass. In Fig. 12, the cells are sorted separately for each experiment and solute. Uniform leaching would give a straight line. Figure 12 shows that $50 \%$ of the drainage and leaching occurred in $12-20 \%$ of the sampler area.

The curves for the drainage lie below the curves of the solutes for both experiments. This can be caused by the longer time period of sampling for the drainage. The solutes were applied as a pulse, and therefore, the sampling period was generally slightly shorter than for the drainage. When the peak concentration of bromide already passed, drainage water was still sampled. Precipitation events after the snow had melted, or the different irrigation rates may result in a varying water storage in the soil. This water storage affects the spatial distribution of the drainage. Therefore, it is more correct to use the leaching instead of the drainage, as the leaching is labelled using a pulse, and the drainage volume itself is not labelled. However, we did include the drainage in Fig. 12, because the sampling period of drainage is not much larger than of bromide, and the drained volumes and leached masses are distributed differently in space (Figs. 4 and 5).

The drainage during the snowmelt experiment lies below the drainage during the irrigation experiment, which implies a larger homogeneity, and strengthens the conclusion based on Fig. 11. 


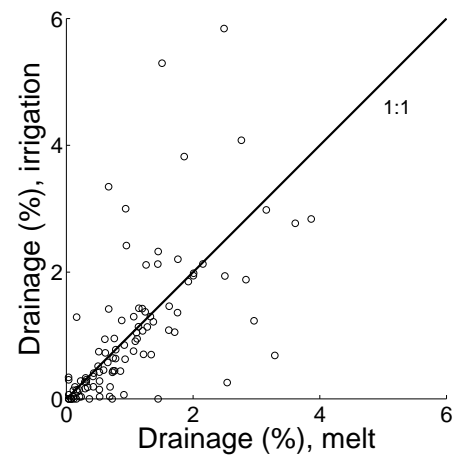

b

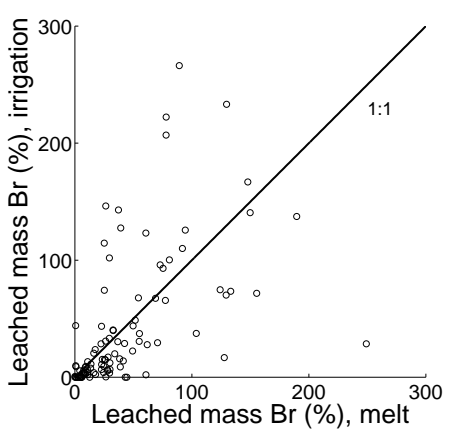

c

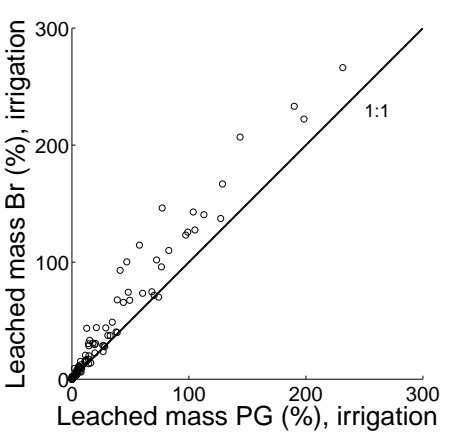

Fig. 13. Comparison of total leaching per cell: drainage of the snowmelt and irrigation experiment (a), bromide leaching of the snowmelt and irrigation experiment (b), and bromide leaching and PG leaching of the irrigation experiment (c). The drainage was scaled with the drainage of the entire sampler of either the snowmelt or irrigation experiment. Solute leaching is given in \% from what would have leached in each cell with perfect uniform flow.

For bromide mass, the curve of the irrigation experiment lies above the curve of the snowmelt experiment. This means that the bromide leaching was more heterogeneous during the irrigation experiment than during the snowmelt experiment. The distances between the curves of the bromide leaching and of the drainage are different for both experiments in Fig. 12. Therefore, we conclude that the heterogeneous solute leaching is both caused by differences in the drainage and the spatial distribution of the solute concentrations. The leaching of bromide and PG during the irrigation experiment was similarly heterogeneous. This was also concluded from Fig. 11.

We studied the stability of the preferential flow paths in the field by comparing the drainage and the bromide leaching in each cell in both experiments (Fig. 13a, b). The total drainage that occurred during the snowmelt experiment and the irrigation experiment had a low linear correlation coefficient $\left(R^{2}=0.43\right)$. Also the total bromide leaching that occurred during the snowmelt experiment and the irrigation experiment were not well correlated $\left(R^{2}=0.56\right)$. We found that the bromide leaching may be different in the exact locations (Fig. 13), even though the area of the MCS with the highest bromide leaching is similar for both experiments (Fig. 11). Thus, the area with the highest leaching is persistent in time, but the exact locations of the highest leaching might change a bit in time.

Comparing the total bromide leaching with the total PG leaching in each cell in the irrigation experiment (Fig. 13c) shows the leached masses per cell were strongly correlated $\left(R^{2}=0.95\right)$. Thus, with the same infiltration rate, the spatial patterns of the leached masses are similar for a degradable solute and a tracer. In Fig. 10, the BTCs for bromide appeared to be different than the BTCs for PG, depending on the division in the fast, average, and slow cells. However, this did not result in a different total PG leaching, relative to the bromide leaching, for the fast, average, and slow cells. Apparently, for
Table 2. Spatial autocorrelation according to Moran's I. A value of 1 indicates perfect spatial autocorrelation, and -0.01 no spatial autocorrelation.

\begin{tabular}{ll}
\hline Experiment and drainage/solute & $I$ \\
\hline Snowmelt drainage $(\mathrm{mm})$ & 0.46 \\
Snowmelt bromide $(\mathrm{mg})$ & 0.61 \\
Irrigation drainage $(\mathrm{mm})$ & 0.14 \\
Irrigation bromide $(\mathrm{mg})$ & 0.26 \\
Irrigation PG $(\mathrm{mg})$ & 0.30 \\
\hline
\end{tabular}

solutes with this degradation rate and under this infiltration rate, the travel time distribution does not influence the overall leaching much.

In Figs. 12 and 13, the cells were approximated as individual stream tubes, while ignoring the possibility of cell clustering. The soil above neighbouring cells could exchange water and solutes, which may have a distinct influence when using a high resolution sampler. We calculated the spatial autocorrelation coefficient of the total drainage and the total leached masses, to determine how the drainage, or the leaching in a particular cell is related to the drainage, or leaching in neighbouring cells. Table 2 shows the values for the spatial autocorrelation coefficient $I$, calculated with Eq. (1). With a high spatial autocorrelation coefficient, the cross-sectional area of the preferential flow paths is large, while with a low spatial autocorrelation the preferential flow paths mainly consist of isolated peaks. The spatial autocorrelation was higher for bromide than for the drainage, for both the snowmelt and the irrigation experiment. As with Fig. 12, this may be a result of the slightly shorter sampling time for leaching than for drainage. During the snowmelt experiment, the spatial autocorrelation was higher than during the irrigation experiment. Thus, with high infiltration rates there is more clustering of high leaching cells. This is consistent 
with Figs. 11 and 12, which show that with a higher water flux the differences in leaching between the cells are smaller. The reason for this might be that with a higher water flux, a larger part of this coarse textured soil is highly conductive. As expected from Fig. 13c, the spatial autocorrelation of PG leaching was similar as that of bromide leaching.

The spatial patterns of the leached masses of bromide and the spatial distribution of the highest bromide concentrations were rather similar for the snowmelt and the irrigation experiment. Therefore, we conclude that soil heterogeneity is the main reason for the heterogeneous water flow and solute transport in this soil. At this scale, the heterogeneous melting of snow does not influence the heterogeneous flow in the soil much. The applied infiltration rate, and the corresponding soil moisture content, influence the differences between the concentrations of the cells. As a result, the areas with the highest leaching were similar for both experiments, but the leached masses in the cells were not highly correlated.

\section{Conclusions}

The leaching of a non-degradable and a degradable solute was measured in two field experiments, with different infiltration rates using a multi-compartment sampler (MCS). The spatial and temporal variability of leaching, and the effect of snowmelt on leaching was quantified, and additionally the leaching of the non-degradable and the degradable solute was compared. One experiment was done during snowmelt, and was characterized by a high infiltration rate from the meltwater. In the other experiment, the soil was irrigated, to mimic homogeneous rainfall with lower infiltration rates.

Regarding the persistence of preferential flow, the highest bromide concentrations were found in the same area for both experiments, and thus were independent of the flow rate. In the snowmelt experiment the spatial differences in the concentrations appeared to be larger than in the irrigation experiment, possibly due to a lower exchange with the surrounding soil (and thus less dilution) caused by the higher infiltration rate.

The highest bromide leaching occurred in the same area for the snowmelt and the irrigation experiments, but not in exactly the same cells. Furthermore, with low infiltration rates, as in the irrigation experiment, there are more isolated peaks in the bromide leaching than in the snowmelt experiment. The heterogeneous flow in the soil, therefore, is probably caused by small changes in the soil hydraulic properties, and not by macropores.

The spatial autocorrelation of the leaching of cells is higher with high infiltration rates. The reason for this might be that with a higher water flux, a larger part of the coarse textured soil is highly conductive.

The highest PG concentrations, and the highest bromide concentrations were found in the same areas in the irrigation experiment. The patterns in the concentrations of a tracer and a degradable solute were similar in space, but not in time, as the leaching of PG started earlier than the leaching of bromide. The leached masses were highly correlated. The leaching of PG was lower than the leaching of bromide, due to degradation.

Soil heterogeneity is the main reason for the heterogeneous water flow and solute transport in this soil. Heterogeneous melting of snow did not influence the heterogeneous flow in the soil much at the scale of the MCS. The applied infiltration rate, and the corresponding soil moisture content, influenced the differences between the concentrations of the cells. As a result the areas with the highest leaching were similar for both experiments, but the leached masses in the cells were not highly correlated.

Acknowledgements. We gratefully acknowledge the financial support of the "Stichting Retourschip", The Netherlands. Part of this research was co-funded by the EU project SoilCAM (FP7, Environmental technologies, contract number: 212663). We thank Kyle Elkin and Gro Eggen for the PG analysis in the laboratory, and assistance in the field.

Edited by: E. Zehe

\section{References}

Allaire, S., Roulier, S., and Cessna, A.: Quantifying preferential flow in soils: a review of different techniques, J. Hydrol., 378, 179-204, 2009.

Bausmith, D. and Neufeld, R.: Soil biodegradation of propylene glycol based aircraft deicing fluids, Water Environ. Res., 71, 459-464, 1999.

Beven, K., Henderson, D., and Reeves, A.: Dispersion parameters for undisturbed partially saturated soil, J. Hydrol., 143, 19-43, 1993.

Bloem, E., Hogervorst, F., and de Rooij, G.: A field experiment with variable-suction multi-compartment samplers to measure the spatio-temporal distribution of solute leaching in an agricultural soil, J. Contam. Hydrol., 105, 131-145, 2009.

Bloem, E., Hogervorst, F., De Rooij, G., and Stagnitti, F.: Variablesuction multicompartment samplers to measure spatiotemporal unsaturated water and solute fluxes, Vadose Zone J., 9, 148-159, 2010.

Boll, J., Selker, J., Shalit, G., and Steenhuis, T.: Frequency distribution of water and solute transport properties derived from pan sampler data, Water Resour. Res., 33, 2655-2664, 1997.

Buchter, B., Hinz, C., Flury, M., and Flühler, H.: Heterogeneous flow and solute transport in an unsaturated stony soil monolith, Soil Sci. Soc. Am. J., 59, 14-21, 1995.

Chenu, C. and Stotzky, G.: Interactions between microoganisms and soil particles: an overview, in: Interactions Between Soil Particles and Microorganisms, edited by: Huang, P., Bollag, J., and Senesi, N., Wiley, Chisester, England, 566 pp., 2002.

De Rooij, G. and Stagnitti, F.: Spatial and temporal distribution of solute leaching in heterogeneous soils: analysis and application to multisampler lysimeter data, J. Contam. Hydrol., 54, 329-346, 2002. 
Feyen, J., Jacques, D., Timmerman, A., and Vanderborght, J.: Modelling water flow and solute transport in heterogeneous soils: a review of recent approaches, J. Agr. Eng. Res., 70, 231-256, 1998.

Flury, M.: Experimental evidence of transport of pesticides through field soils-a review, J. Environ. Qual., 25, 25-45, 1996.

French, H. and Van der Zee, S.: Field observations of small scale spatial variability of snowmelt drainage and infiltration, Nord. Hydrol., 30, 161-176, 1999.

French, H., Swensen, B., Englund, J., Meyer, K., and Van der Zee, S.: A lysimeter trench for reactive pollutant transport studies, in: Future Groundwater Resources at Risk, edited by: Soveri, J. and Suokko, T., IAHS-AISH P., Wallingford, Oxfordshire, 222, 131-138, 1994.

French, H., Van der Zee, S., and Leijnse, A.: Transport and degradation of propyleneglycol and potassium acetate in the unsaturated zone, J. Contam. Hydrol., 49, 23-48, 2001.

Holder, M., Brown, K., Thomas, J., Zabcik, D., and Murray, H.: Capillary-wick unsaturated zone soil pore water sampler, Soil Sci. Soc. Am. J., 55, 1195-1202, 1991.

Jaesche, P., Totsche, K., and Kogel-Knabner, I.: Transport and anaerobic biodegradation of propylene glycol in gravel-rich soil materials, J. Contam. Hydrol., 85, 271-286, 2006.

Jarvis, N.: A review of non-equilibrium water flow and solute transport in soil macropores: principles, controlling factors and consequences for water quality, Eur. J. Soil Sci., 58, 523-546, 2007.

Kasteel, R., Pütz, T., and Vereecken, H.: An experimental and numerical study on flow and transport in a field soil using zerotension lysimeters and suction plates, Eur. J. Soil Sci., 58, 632645, 2007

Kilfrost: Kilfrost DF Plus (88) material safety data sheet, available at: http://www.kilfrost.com/documents/DF88-MSDS. pdf (last access: 24 February 2012), 2012.

Lennartz, B., Jarvis, N., and Stagnitti, F.: Effects of heterogeneous flow on discharge generation and solute transport, Soil Sci., 173, 306-320, 2008.

Lißner, H., Wehrer, M., Bloem, E., and Totsche, K.: Soil heterogenity strongly affects fate and transport of deicing chemicals, Geophys. Res. Abstr., EGU2011-7529-1, EGU General Assembly 2011, Vienna, Austria, 2011.

Marsh, P.: Water flux in melting snow covers, in: Advances in Porous Media, edited by: Corapcioglu, M. Y., Elsevier, Amsterdam, 61-124, 1991.

Öhrström, P., Hamed, Y., Persson, M., and Berndtsson, R.: Characterizing unsaturated solute transport by simultaneous use of dye and bromide, J. Hydrol., 289, 23-35, 2004.
Poletika, N. N. and Jury, W. A.: Effects of soil surface management on water flow distribution and solute dispersion, Soil Sci. Soc. Am. J., 58, 999-1006, 1994.

Pot, V., Simunek, J., Benoit, P., Coquet, Y., Yra, A., and MartínezCordón, M.: Impact of rainfall intensity on the transport of two herbicides in undisturbed grassed filter strip soil cores, J. Contam. Hydrol., 81, 63-88, 2005.

Quisenberry, V., Phillips, R., and Zeleznik, J.: Spatial distribution of water and chloride macropore flow in a well-structured soil, Soil Sci. Soc. Am. J., 58, 1294-1294, 1994.

Roth, K.: Steady state flow in an unsaturated, two-dimensional, macroscopically homogeneous, Miller-similar medium, Water Resour. Res., 31, 2127-2140, 1995.

Šimunek, J., Jarvis, N., Van Genuchten, M., and Gärdenäs, A.: Review and comparison of models for describing non-equilibrium and preferential flow and transport in the vadose zone, J. Hydrol., 272, 14-35, 2003

Stotzky, G.: Soil as an environment for microbial life, in: Modern Soil Microbiology, edited by: Van Elsas, J., Trevors, J., and Wellington, E., Marcel Dekker, New York, 683 pp., 1997.

Strock, J., Cassel, D., and Gumpertz, M.: Spatial variability of water and bromide transport through variably saturated soil blocks, Soil Sci. Soc. Am. J., 65, 1607-1617, 2001.

Toride, N., Leij, F., and Van Genuchten, M.: The CXTFIT Code for Estimating Transport Parameters from Laboratory or Field Tracer Experiments. Version 2.0, US Salinity Laboratory, USDA, ARS, Riverside, CA, 121 pp., 1995.

Vanderborght, J. and Vereecken, H.: Review of dispersivities for transport modeling in soils, Vadose Zone J., 6, 29-52, 2007.

Waldner, P., Schneebeli, M., Schultze-Zimmermann, U., and Flühler, H.: Effect of snow structure on water flow and solute transport, Hydrol. Process., 18, 1271-1290, 2004.

Weihermüller, L., Siemens, J., Deurer, M., Knoblauch, S., Rupp, H., Göttlein, A., and Pütz, T.: In situ soil water extraction: A review, J. Environ. Qual., 36, 1735-1748, 2007.

Wierenga, P.: Solute distribution profiles computed with steadystate and transient water movement models, Soil Sci. Soc. Am J., 41, 1050-1055, 1977.

Williams, A. G., Dowd, J. F., Scholefield, D., Holden, N. M., and Deeks, L. K.: Preferential flow variability in a well-structured soil, Soil Sci. Soc. Am. J., 67, 1272-1281, 2003. 